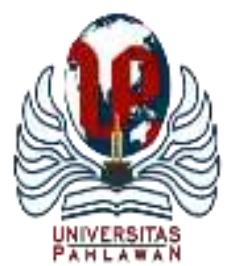

\title{
JURNALBASICEDU
}

Volume 5 Nomor 5 Tahun 2021 Halaman 3566 - 3578

Research \&Learningin Elementary Education

https://jbasic.org/index.php/basicedu

\section{Peningkatan Hasil Belajar Siswa dengan Menggunakan Metode Montessori pada Siswa Sekolah Dasar}

\author{
Bisron Mangait Tua Sitinjak ${ }^{1 凶}$, Dewi Anzelina ${ }^{2}$, Saut Mahulae ${ }^{3}$, Patri Janson Silaban ${ }^{4}$ \\ Universitas Katolik Santo Thomas, Indonesia ${ }^{1,2,3,4}$ \\ E-mail: bisron.sitinjak11@gmail.com ${ }^{1}, \underline{\text { dewianzelina1988@gmail.com }}^{2}$, mahulaesaut@gmail.com ${ }^{3}$, \\ patri.jason.silaban@gmail.com ${ }^{4}$
}

\begin{abstract}
Abstrak
Metode yang digunakan dalam penelitian ini adalah metode penelitian tindakan kelas. Penelitian ini bertujuan untuk: (1) untuk mengetahui pelaksanaan pembelajaran dengan menggunakan metode montessori di kelas $\mathrm{V}$ SD Negeri 066650 Medan Kota Tahun Pembelajaran 2020/2021. (2) untuk mengetahui pendekatan metode montessori pada pelajaran Tematik Tema Lingkungan Sahabat Kita di kelas V SD Negeri 066650 Medan kota Tahun Pembelajaran 2020/2021. Teknik pengumpulan data melalui pengamatan terhadap tes hasil belajar, aktivitas belajar siswa. Aktivitas belajar siswa siklus I dengan rata-rata skor sebesar 59 dengan kategori cukup dan aktivitas siswa pada siklus II sebesar 96 dengan kategori sangat baik. Dengan demikian berdasarkan hasil tersebut maka terjadi peningkatan sebesar $37 \%$. Hasil belajar siswa siklus I dan siklus II diketahui bahwa nilai rata- rata tes evaluasi dari 68 menjadi 76,48. Ketuntasan belajar siswa pada siklus I sebesar 48\%, sedangkan pada siklus II sebesar 88\%. Dengan demikian, peningkatan yang terjadi sebesar $40 \%$. Maka dengan menerapkan metode montessori dalam proses pembelajaran dapat meningatkan hasil belajar siswa.
\end{abstract}

Kata Kunci: Metode montessori, Aktivitas dan hasil belajar.

\section{Abstract}

The method used in this research is the classroom action research method. This study aims to: (1) To determine the implementation of learning using the Montessori method in class V SD Negeri 066650 Medan City for the 2020/2021 academic year. (2) To find out the approach of the Montessori method in the Thematic lesson on the Environmental Theme of Our Friends in class V SD Negeri 066650 Medan City for the 2020/2021 academic year. Data collection techniques through observation of learning outcomes tests, student learning activities. Student learning activities in the first cycle with an average score of 59 with a sufficient category and student activities in the second cycle of 96 with a very good category. Thus, based on these results, there was an increase of 37\%. Student learning outcomes in cycle I and cycle II are known that the average value of the evaluation test is from 68 to 76.48. Student learning completeness in the first cycle is $48 \%$, while in the second cycle it is $88 \%$. Thus, the increase occurred by $40 \%$. So by applying the Montessori method in the learning process can improve student learning outcomes.

Keywords: Montessori method, Activities and learning outcomes.

Copyright (c) 2021 Bisron Mangait Tua Sitinjak, Dewi Anzelina, Saut Mahulae, Patri Janson Silaban

$\triangle$ Corresponding author :

Email : bisron.sitinjak11@gmail.com

DOI : $\quad$ https://doi.org/10.31004/basicedu.v5i5.1008 
3567 Peningkatan Hasil Belajar Siswa dengan Menggunakan Metode Montessori pada Siswa Sekolah Dasar - Bisron Mangait Tua Sitinjak, Dewi Anzelina, Saut Mahulae, Patri Janson Silaban

DOI: https://doi.org/10.31004/basicedu.v5i5.1008

\section{PENDAHULUAN}

Pendidikan merupakan wahana untuk menuntut berbagai ilmu pengetahuan. Dalam proses pendidikan, potensi dan kemampuan yang dimiliki siswa diasah sedemikian rupa sehingga potensi tersebut tidak terpendam melainkan muncul dipermukaan dan akhirnya menjadi sumber daya manusia yang handal dan profesional. Peningkatan mutu pendidikan harus terus menerus dipacu agar mampu mengimbangi perkembangan jaman sebagai upaya untuk mempersiapkan sumber daya manusia yang berkualitas. Salah satu indikator pendidikan berkualitas adalah perolehan hasil belajar yang maksimal oleh siswa, baik itu hasil belajar dalam bentuk kognitif, efektif maupun psikomotor. Hasil belajar siswa sangat dipengaruhi oleh kegiatan proses belajar mengajar yang di dalamnya terdapat beberapa faktor yang merupakan penentu lancar atau tidaknya kegiatan proses belajar mengajar.

Untuk meningkatkan kualitas pendidikan, berbagai cara telah dilakukan dalam dunia pendidikan dimulai dari sekolah dasar hingga perguruan tinggi. Dalam pembelajaran peserta didik diharuskan aktif agar dapat belajar sesuai dengan bakat dan segala potensi yang dimilikinya. Keaktifan peserta didik dapat diwujudkan baik keaktifan fisik maupun keaktifan mental. Interaksi yang baik antara guru dan peserta didik sangat diperlukan agar proses pembelajaran dapat berlangsung efektif. Interaksi belajar mengajar dapat dilakukan dengan mengaktifkan peserta didik menggunakan teknik tanya jawab atau dialog yang interaktif dalam proses pembelajaran. Adanya interaksi multi arah secara langsung akan membuat pembelajaran lebih bermakna.

Dalam Kegiatan mengajar, metode pembelajaran juga sangat penting. Maka dari itu guru harus mampu menguasai berbagai metode pembelajaran yang dapat membuat peserta didik semakin aktif dan mampu menangkap pembelajaran tersebut. Selama ini kebanyakan proses pembelajaran selalu menggunakan metode ceramah dan pemberian tugas, sehingga proses pembelajaran terlalu monoton dan hanya berpusat pada guru. Dan ketika memberikan materi banyak siswa yang kurang paham apa yang disampaikan oleh guru. Dalam pembelajaran ada berbagai macam metode pembelajaran, salah satunya adalah Metode Montessori yang akan diterapkan pada proses pembelajaran.

Penelitian yang dilakukan oleh Putri Sekar Arum Pada tahun 2019 yang berjudul " Peningkatan Hasil Belajar Siswa Kelas IV SD Menggunakan Media Pembelajaran IPA Berbasis Metode Montessori Pada Materi Perakaran Tumbuhan". Hasil penelitian ini menunjukkan bahwa ada peningkatan motivasi dan minat belajar siswa pada pokok bahasan bangun ruang. Hal ini dapat dilihat kemauan siswa untuk mengerjakan tugas dari guru sebelum dilakukan tindakan sebesar 46,5\% (20 siswa) di akhir putaran menjadi 90,7\% (39 siswa) dan perhatian siswa pada saat poses belajar mengajar sebelum dilakukan tindakan sebesar $0 \%$ di akhir putaran menjadi 75,67\% (28 siswa). Sedangkan peningkatan motivasi dan minat belajar siswa dilihat dari hasil belajar siswa mencapai $75 \%$ dengan nilai diatas 75 sebelum diadakan penelitian sebesar 38,4\% (15 siswa) diakhir putaran menjadi 86,04\% (37 siswa). Berdasarkan hasil penelitian disimpulkan bahwa pembelajaran melalui metode montessori dengan menggunakan alat peraga pada pokok bahasan bangun ruang dapat meningkatkan motivasi dan minat belajar siswa sampai $75 \%$.

Berdasarkan observasi yang dilakukan peneliti dengan wali kelas V SD Negeri 066650 Medan Kota, data hasil belajar siswa pada pembelajaran tema "Lingkungan Sahabat Kita" masih sangat rendah. Hal ini disebabkan karena guru jarang menggunakan metode dalam proses pembelajaran sehingga kurangnya minat belajar siswa dalam proses pembelajaran, dan proses pembelajaran dikelas sangat membosankan bagi siswa karena, guru lebih aktif dibandingkan siswa. dan kegiatan belajar di kelas bersifat satu arah (konvensional), mengakibatkan hasil belajar siswa sangat rendah. 
3568 Peningkatan Hasil Belajar Siswa dengan Menggunakan Metode Montessori pada Siswa Sekolah Dasar - Bisron Mangait Tua Sitinjak, Dewi Anzelina, Saut Mahulae, Patri Janson Silaban

DOI: https://doi.org/10.31004/basicedu.v5i5.1008

Tabel 1 Hasil Nilai Siswa Kelas V SD Negeri 066650 Medan KotaTahun Pelajaran 2019/2020 Tema 8 Lingkungan Sahabat Kita

\begin{tabular}{cllcl}
\hline $\begin{array}{c}\text { Muatan Mata } \\
\text { Pelajaran }\end{array}$ & Nilai KKM & $\begin{array}{c}\text { Jumlah } \\
\text { Siswa }\end{array}$ & Presentase(\%) & \multicolumn{1}{c}{$\begin{array}{c}\text { Keterangan } \\
\text { Ketuntasan }\end{array}$} \\
\hline \multirow{2}{*}{ Bahasa Indonesia } & $>70$ & 12 & $48 \%$ & Tuntas \\
\cline { 2 - 5 } & $<70$ & 13 & $52 \%$ & Tidak Tuntas \\
\hline \multirow{2}{*}{ IPA } & $>70$ & 10 & $40 \%$ & Tuntas \\
\cline { 2 - 5 } & $<70$ & 15 & $60 \%$ & Tidak Tuntas \\
\hline \multirow{2}{*}{ SBDP } & $>70$ & 6 & $24 \%$ & Tuntas \\
\cline { 2 - 5 } & $<70$ & 19 & $76 \%$ & Tidak Tuntas \\
\hline Jumlah & & 25 Siswa & $100 \%$ & Tuntas \\
\hline
\end{tabular}

Sumber : Daftar Nilai Siswa Kelas V SD Negeri 066650 Medan Kota Tema 8 Lingkungan Sahabat Kita.

Dari tabel di atas diketahui bahwa hasil belajar siswa pada pembelajaran tema "Lingkungan Sahabat Kita" yang diperoleh pada semester genap dari 25 jumlah siswa pada saat ulangan formatif, pada pembelajaran bahasa Indonesia yang tidak tuntas 13 siswa atau 52\% dan yang tuntas 12 siswa atau $48 \%$ yang mencapai KKM, pada IPA yang tidak tuntas 15 siswa atau $60 \%$ dan yang tuntas 10 siswa atau $40 \%$ yang mencapai KKM, pada SBDP yang tidak tuntas 19 siswa atau 76\% dan yang tuntas 6 siswa atau 24\% yang mencapai KKM. Kriteria Ketuntasan Minimal (KKM) yaitu 70 pada pembelajaran tematik. Ini artinya ketuntasan hasil belajar pada pembelajaran tematik sangat rendah. Menurut guru kelas V masalah ketidaktuntasan hasil belajar siswa ini terjadi setiap semester.

Setelah mempelajari permasalahan di atas peneliti tertarik dalam pemberian solusi kepada guru untuk menggunakan metode montessori yang disebut dengan belajar sambil bermain dengan menggunakan mediamedia pembelajaran yang sesuai dengan kebutuhan siswa. Menurut (Zahidi 2020), mengatakan bahwa metode montessori adalah sebuah metode pendidikan bagi anak yang dalam penyusunannya berdasarkan pada teori perkembangan anak. Karakteristik dari metode ini adalah menekankan pada aktivitas yang dimunculkan oleh diri anak dan menekankan pada adaptasi lingkungan belajar anak pada level perkembangannya dan peran dari aktivitas fisik dalam menyerap konsep pembelajaran dan kemampuan praktis. Sesuatu yang lebih utama bagi gagasan montessori yang menyatakan bahwa pendidikan harus terus berjalan sesuai dengan perkembangan. Sebagian besar keputusan yang diambil oleh para pendidik melalui kurikulum dan aktivitas pendukungnya didorong tujuan-tujuan kurikulum atau keharusan anak didik mengerjakan soal-soal ujian (materi) berdasarkan usia kronologis tertentu tanpa memeperdulikan tahap perkembangan individu anak. Peneliti berharap dengan diterapkannya metode montessori ini akan dapat meningkatkan hasil belajar siswa dalam pembelajaran tematik.

\section{METODE PENELITIAN}

Metode yang digunakan dalam penelitian ini adalah metode penelitian tindakan kelas. Pemilihan metode ini didasari sebagai upaya peningkatan hasil belajar yang berlangsung dalam tahapan siklus. Bermula dari perencanaan (planning), pelaksanaan (action), pengamatan (observasi), dan refleksi (reflection) dan kembali pada perencanaan untuk tindakan kelas.

Subjek penelitian adalah siswa kelas V yang berjumlah 25 siswa. Peneliti memilih kelas V sebagai subjek penelitian didasarkan pada hasil observasi. Desain penelitian yang digunakan dalam penelitian ini adalah merencanakan perangkat pembelajaran dan instrument tes untuk 2 siklus dengan masing-masing siklus 3 kali pertemuan. Setiap siklus dilaksanakan dengan 4 tahap, yaitu: perencanaan, pelaksanaan, observasi, refleksi. 
3569 Peningkatan Hasil Belajar Siswa dengan Menggunakan Metode Montessori pada Siswa Sekolah Dasar - Bisron Mangait Tua Sitinjak, Dewi Anzelina, Saut Mahulae, Patri Janson Silaban

DOI: https://doi.org/10.31004/basicedu.v5i5.1008

Teknik pengumpulan data yang dilakukan dalam penelitian ini adalah dengan menggunakan teknik observasi dan teknik tes. Observasi dilakukan untuk mengamati kegiatan di kelas selama kegiatan pembelajaran. Kegiatan yang diamati meliputi aktivitas guru dan siswa selama kegiatan pembelajaran.Tes yang digunakan dalam penelitian ini adalah pilihan berganda untuk mengukur hasil belajar siswa.

Instrumen yang dipakai dalam penelitian ini adalah menggunakan lembar observasi kegiatan pembelajaran dan lembaran soal pengukur hasil belajar. Sebelum digunakan instrumen terlebih dahulu dilakukan uji validitasnya agar instrumen benar-benar dapat digunakan dengan hasil sesuai yang diharapkan.

\section{HASIL DAN PEMBAHASAN}

Peneitian ini dilaksanakan sebanyak 2 siklus yang meliputi perencanaan, pelaksanaan, observasi, dan refleksi. Dalam pelaksanaan penelitian ini, peneliti dan guru melakukan kerjasama dengan peneliti bertindak sebagai guru dan guru bertindak sebagai pengamat yang mengamati kegiatan guru dan siswa dalam proses belajar mengajar bertujuan untuk meningkatkan hasil belajar siswa. Faktor penting yang mempengaruhi hasil belajar siswa salah satunya pendekatan belajar. Salah satu bagian dari faktor pendekatan belajar adalah penggunaan model pembelajaran yang bervariasi pada saat penyampaian materi kepada siswa yang membuat pembelajaran menjadi menarik dan tidak membosankan dalam mengikuti pembelajaran.

Pada situasi pandemic Covid-19 ditahun ini pemerintah menerapkan beberapa kebijakan untuk mengatasinya beberapa masalah yang terjadi dimasyarakat salah satunya dibidang pendidikan yaitu meliburkan siswa dan mulai menerapkan metode belajar dengan sistem daring atau online. Ada beberapa sekolah yang tidak siap dengan sistem pembelajaran daring, karena membutuhkan beberapa media pembelajaran yang tidak semua siswa mampu memilikinya seperti handphone dan jaringan internet serta kuota yang membutuhkan biaya yang cukup tinggi harganya bagi siswa untuk kebutuhan pembelajaran daring dan guru harus menyedihkan laptop atau komputer untuk mengajar kepada siswa secara online.

Dengan kondisi situasi seperti itu peneliti juga menemukan situasi yang sama di sekolah tempat penelitian yang akan diteliti, maka pihak sekolah dan orang tua siswa bekerjasama agar pembelajaran dilakukan dirumah dan melakukan pembelajaran secara tatap muka di sekolah selama seminggu 2 kali dengan memperhatikan protokol kesehatan yang telah diterapkan yaitu selalu menjaga jarak, kesehatan dan kebersihan.

Peneliti melakukan pengamatan terhadap kondisi kelas saat guru menerangkan dan mengamati guru mengajar tanpa model pembelajaran. Guru hanya menggunakan metode ceramah dan tidak menciptakan pembelajaran yang menarik dan menyenangkan. Setelah melakukan pengamatan terhadap guru, peneliti melakukan pratest kepada siswa untuk mengetahui pemahaman awal siswa terhadap tema "Lingkungan Sahabat Kita". Pelaksanaan pratest ini juga bertujuan untuk mengetahui gambaran-gambaran kesulitan yang dialami oleh siswa dalam menjawab soal-soal pada tema "Lingkungan Sahabat Kita".

\section{Ketuntasan Hasil Belajar Siswa Secara Klasikal Pada Pratest}

Setelah diketahui ketuntasan individual, selanjutnya ketuntasan secara klasikal yang dilihat dari hasil belajar siswa dalam satu kelas. Ketuntasan hasil belajar siswa secara klasikal pada pratest dapat dilihat pada tabel berikut :

Tabel 2 Ketuntasan Hasil Belajar Siswa Secara Klasikal Pada Pratest

\begin{tabular}{lcc}
\hline \multicolumn{1}{c}{ Keterangan } & \multicolumn{2}{c}{ Siklus I } \\
\cline { 2 - 3 } & Jumlah Siswa & Presentase \\
\hline Jumlah Siswa Yang Tuntas & 8 & $32 \%$ \\
\hline Jumlah Siswa Yang Tidak Tuntas & 17 & $68 \%$ \\
\hline Jumlah Siswa & 25 & $100 \%$ \\
\hline
\end{tabular}


3570 Peningkatan Hasil Belajar Siswa dengan Menggunakan Metode Montessori pada Siswa Sekolah Dasar - Bisron Mangait Tua Sitinjak, Dewi Anzelina, Saut Mahulae, Patri Janson Silaban

DOI: https://doi.org/10.31004/basicedu.v5i5.1008

\section{Rata-rata Hasil Belajar Siswa Pada Pra Test}

Dari hasil ketentuan belajar individu dan klasikal maka dapat diperoleh nilai rata-rata hasil belajar siswa dengan menggunakan rumus sebagai berikut:

$$
\begin{aligned}
& \mathrm{x}=\frac{\sum x}{\sum N} \\
& \mathrm{x}=\frac{1327}{25} \\
& \mathrm{x}=53.08
\end{aligned}
$$

\section{Hasil Penelitian Siklus I}

\section{Ketuntasan Hasil Belajar Siswa Secara Individu Pada Siklus I}

Dari hasil belajar yang diperoleh peneliti pada penelitian tindakan kelas (PTK) pada siklus I di SD Negeri 066060 Medan Kota kelas V pada tema "Lingkungan Sahabat Kita" subtema "Manusia dan Lingkungan" pada pembelajaran 1 dengan metode montessori, berdasarkan nilai kriteria ketuntasan minimal (KKM) yakni 70 maka diperolah ketuntasan hasil belajar siswa secara individu yang ditunjukkan pada gambar.

Ketuntasan hasil belajar secara individu dapat dilihat pada grafik dibawah ini:

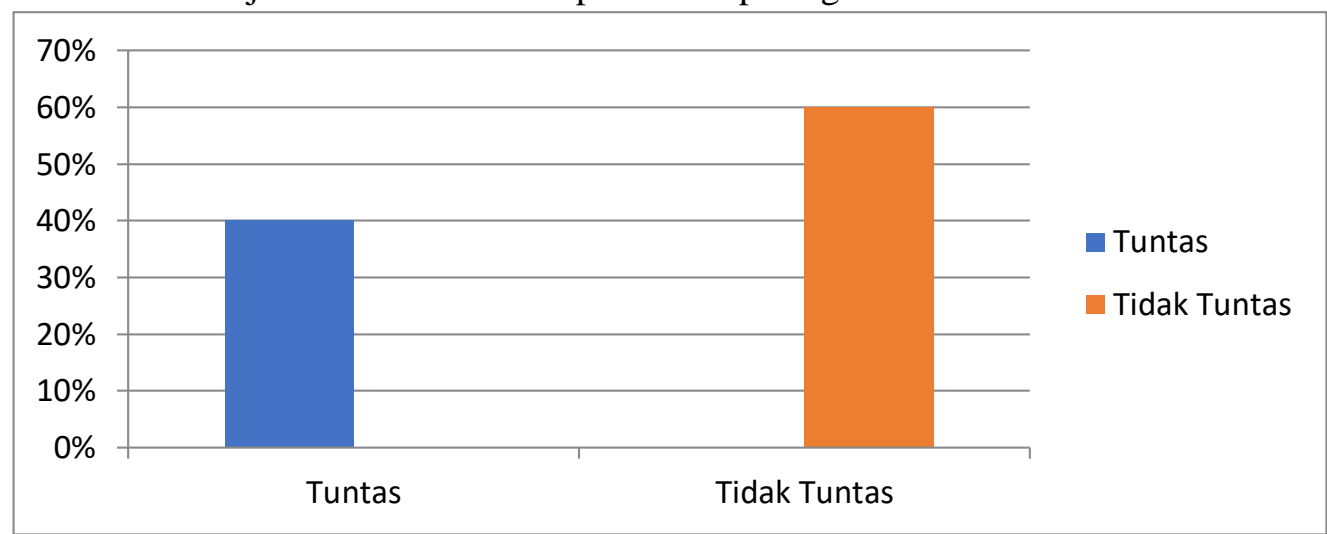

Grafik 1 Ketuntasan Hasil Belajar Siswa Pada Test Siklus I

\section{Ketuntasan Hasil Belajar Siswa Secara Klasikal Pada Siklus I}

Setelah diketahui ketuntasan individu, selanjutnya ketuntasan secara klasikal dilihat dari hasil belajar siswa dalam satu kelas. Siswa yang dikatakan tuntas hasil belajar secara klasikal jika didalam kelas tersebut 75\% siswa yang dapat nilai tuntas dan mencapai Kriteria Ketuntasan Minimal (KKM) yang telah ditetapkan yaitu 70. Ketuntasan hasil belajar siswa secara klasikal dapat dilihat pada table yang terdapat persentase ketuntasan hasil belajar siswa secara klasikal pada siklus I adalah :

Tabel 3 Ketuntasan Hasil Belajar Siswa Secara Klasikal Pada Post Test Siklus I

\begin{tabular}{lcc}
\hline \multicolumn{1}{c}{ Keterangan } & \multicolumn{2}{c}{ Siklus I } \\
\cline { 2 - 3 } & Jumlah Siswa & Presentase \\
\hline Jumlah Siswa Yang Tuntas & 10 & $40 \%$ \\
\hline Jumlah Siswa Yang Tidak Tuntas & 15 & $60 \%$ \\
\hline Jumlah Siswa & 25 & $100 \%$ \\
\hline
\end{tabular}

\section{Rata-rata Hasil Belajar Siswa Pada Siklus I}

Dari hasil ketuntasan belajar individu dan klasikal maka dapat diperoleh rata-rata hasil belajar siswa dapat dihitung dengan menggunakan rumus sebagai berikut:

$$
\begin{aligned}
& \mathrm{x}=\frac{\sum x}{\sum N} \\
& \mathrm{x}=\frac{1465}{25} \\
& \mathrm{x}=59
\end{aligned}
$$


3571 Peningkatan Hasil Belajar Siswa dengan Menggunakan Metode Montessori pada Siswa Sekolah Dasar - Bisron Mangait Tua Sitinjak, Dewi Anzelina, Saut Mahulae, Patri Janson Silaban

DOI: https://doi.org/10.31004/basicedu.v5i5.1008

Berdasarkan data yang telah diperoleh pada siklus I dapat diketahui bahwa dari 25 orang siswa setelah diberikan tindakan yaitu metode montessori menunjukkan bahwa pada siklus I terdapat 10 orang siswa yang tuntas belajar dengan presentase $40 \%$ dan nilai rata-raa kelas yaitu 59 .

\section{Hasil Observasi Aktivitas Guru Pada Siklus I}

Tahap pengamatan pada siklus I dilakukan oleh penelitian yang dibantu oleh guru kelas yang dimulai dari awal pelaksanaan tindakan pembelajaran pada sub tema Manusia Dan Lingkungan. Pengamatan ini dilaksanakan selama proses belajar mengajar berlangsung untuk mengamati sejauh mana keberhasilan peneliti dan siswa dalam proses belajar mengajar dengan menerapkan metode montessori. Adapun pengamatan yang dilakukan adalah sebagai berikut:

Tabel 4 Lembar Observasi Aktivitas Guru Siklus I

\begin{tabular}{|c|c|c|c|c|c|c|}
\hline \multirow{2}{*}{ No } & \multirow{2}{*}{ Aspek yang Diobservasi } & \multicolumn{5}{|c|}{ Penilaian } \\
\hline & & 1 & 2 & 3 & 4 & 5 \\
\hline 1. & Membuka pelajaran dan apersepsi & & & $\sqrt{ }$ & & \\
\hline 2. & Menyampaikan topik dan tujuan pembelajaran & & & & $\sqrt{ }$ & \\
\hline 3. & $\begin{array}{l}\text { Melaksanakan pembelajaran sesuai dengan rencana pelaksanaan } \\
\text { pembelajaran( RPP) }\end{array}$ & & & & $\sqrt{ }$ & \\
\hline 4. & Membagikan kelompok yang bersifat heterogen & & & & $\sqrt{ }$ & \\
\hline 5. & Membimbing diskusi kelompok yang bersifat heterogen & & & $\sqrt{ }$ & & \\
\hline 6. & Memotivasi siswa untuk bertanya dan menjawab pertanyaan & & & & $\sqrt{ }$ & \\
\hline 7. & Volume dan nada suara yang jelas & & & $\sqrt{ }$ & & \\
\hline 8. & Mengadakan Evaluasi & & & & & $\sqrt{ }$ \\
\hline 9. & $\begin{array}{l}\text { Membuat rangkuman (kesimpulan) sesuai dengan model pembelajaran } \\
\text { yang sudah ditetapkan }\end{array}$ & & & & $\sqrt{ }$ & \\
\hline 10. & Menutup pelajaran & & & & & $\sqrt{ }$ \\
\hline & Jumlah & & & 39 & & \\
\hline
\end{tabular}

Berdasarkan tabel diatas jumlah yang diperoleh peneliti saat bertindak sebagai guru dalam penelitian Upaya Meningkatkan Hasil Belajar Siswa Dengan Penerapan metode montessori Pada Tema Lingkungan Sahabat Kita Dikelas V SDN 066650 Medan Kota Tahun Pembelajaran 2020/2021 pada siklus I berjumlah 39 dengan presentase $78 \%$ dengan kriteria baik.

\section{Hasil Observasi Aktivitas Siswa Pada Siklus I}

Peneliti juga mengobservasi kemampuan siswa. Tujuan dari observasi adalah untuk menilai sikap (afektif) dan Keterampilan (psikomotorik) siswa dalam mengikuti proses pembelajaran dilaksanakan dengan menerapkan metode montessori. Hasil observasi aktivitas siswa pada siklus I dapat dilihat pada tabel dibawah ini.

Tabel 5 Lembar Observasi untuk Aktivitas Siswa Siklus I

\begin{tabular}{|c|c|c|c|c|c|c|}
\hline \multirow{2}{*}{ No } & \multirow{2}{*}{ Aspek yang Diobservasi } & \multicolumn{5}{|c|}{ Penilaian } \\
\hline & & $\mathbf{1}$ & 2 & 3 & 4 & 5 \\
\hline & Kesiapan menerima pelajaran & & & $\sqrt{ }$ & & \\
\hline 2. & Ketenangan mempelajari materi & & & $\sqrt{ }$ & & \\
\hline 3. & Aktivitas kerjasama dalam kelompok & & & & $\sqrt{ }$ & \\
\hline 4. & Keaktifan siswa dalam menjawab pertanyaan guru didalam kelompok & & & & $\sqrt{ }$ & \\
\hline 5. & Keaktifan menjelaskan didepan kelas & & & $\sqrt{ }$ & & \\
\hline & Tanggung jawab siswa dalam persentasi kelompok & & & $\sqrt{ }$ & & \\
\hline & Pemahaman siswa dalam bekerja kelompok & & & $\sqrt{ }$ & & \\
\hline 8. & Penguasaan siswa dalam bekerja kelompok & & & & $\sqrt{ }$ & \\
\hline
\end{tabular}


3572 Peningkatan Hasil Belajar Siswa dengan Menggunakan Metode Montessori pada Siswa Sekolah Dasar - Bisron Mangait Tua Sitinjak, Dewi Anzelina, Saut Mahulae, Patri Janson Silaban

DOI: https://doi.org/10.31004/basicedu.v5i5.1008

\begin{tabular}{llcl}
\hline 9. & Penguasaan siswa dalam mengerjakan tugas kelompok & $\sqrt{ }$ \\
\hline 10. & Mengerjakan soal tes dengan baik & $\sqrt{ }$ \\
\hline Jumlah & 34 & \\
\hline
\end{tabular}

Berdasarkan tabel hasil pengamatan aktivitas siswa diatas, kegiatan yang dilakukan oleh peneliti yang bertindak sebagai guru selama proses pembelajaran dengan menggunakan metode montessori termasuk kategori cukup untuk meningkatkan hasil belajar siswa. Hal ini dapat dibuktikan dari hasil observasi aktivitas siswa nilai yang diperoleh yaitu 68 dengan kriteria cukup.

\section{Hasil Penelitian Siklus II}

\section{Hasil Belajar Siswa Secara Individu Siklus II}

Dari hasil belajar yang diperoleh peneliti pada Penelitian Tindakan Kelas (PTK) pada siklus I di SD Negeri 066650 Medan Kota Kelas V pada tema "Lingkungan Sahabat Kita" subtema "Manusia Dan Lingkungan" dengan menggunakan metode montessori masih banyak siswa yang belum tuntas dan belum mencapai KKM yaitu sebanyak 15 siswa. Pada siklus II hasil belajar siswa mengalami peningkatan yaitu siswa yang tuntas belajar dan mencapai KKM sebanyak 22 siswa dan yang tidak tuntas dan belum mencapai KKM yaitu sebanyak 3 siswa. Ketuntasan secara individu dapat dilihat perbandingannya pada grafik dibawah ini:

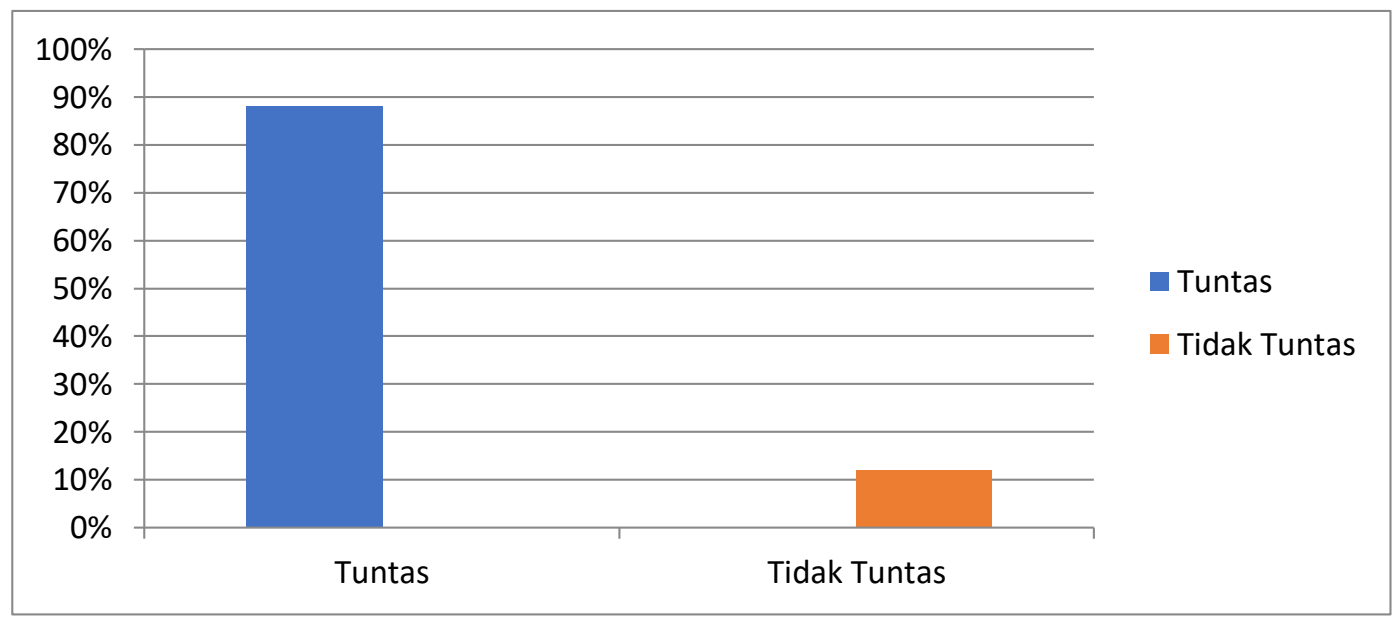

\section{Grafik 2 Ketuntasan Hasil Belajar Siswa Pada Post Test siklus II}

\section{Ketuntasan Hasil Belajar Siswa Secara Klasikal Pada Siklus II}

Berdasarkan hasil belajar yang diperoleh peneliti pada tindakan siklus I hasil belajar siswa secara klasikal belum tuntas karena belum mencapai $75 \%$ tetapi hanya mencapai $40 \%$. Pada pelaksanaan siklus II terjadi peningkatan terhadap hasil belajar siswa secra klasikal yaitu $88 \%$ dengan kriteria sangat tinggi. Untuk lebih jelasnya dapat dilihat pada tabel berikut:

Tabel 6 Ketuntasan Hasil Belajar Siswa Secara Klasikal Pada Siklus II

\begin{tabular}{lcc}
\hline Keterangan & \multicolumn{2}{c}{ Siklus II } \\
\cline { 2 - 3 } & Jumlah Siswa & Presentase \\
\hline Jumlah Siswa Yang Tuntas & 22 & $88 \%$ \\
\hline Jumlah Siswa Yang Tidak Tuntas & 3 & $12 \%$ \\
\hline Jumlah Siswa & 25 & $100 \%$ \\
\hline
\end{tabular}


3573 Peningkatan Hasil Belajar Siswa dengan Menggunakan Metode Montessori pada Siswa Sekolah Dasar - Bisron Mangait Tua Sitinjak, Dewi Anzelina, Saut Mahulae, Patri Janson Silaban

DOI: https://doi.org/10.31004/basicedu.v5i5.1008

\section{Rata-rata Hasil Belajar Siswa Pada Siklus II}

Dari hasil ketuntasan belajar individu dan kalsikal maka dapat diperoleh nilai rata-rata hasil belajar siswa yang dapat dihitung dengan rumus berikut:

$$
\begin{aligned}
& X=\frac{23}{25} \\
& X=\frac{1912}{25} \\
& X=76,48
\end{aligned}
$$

\section{Hasil Observasi Aktivitas Guru Pada Siklus II}

Peneliti ini melibatkan guru kelas V SD Negeri 066650 Medan Kota. Guru kelas bertindak sebagai pengamat dan peneliti bertindak sebagai guru. Dalam pelaksanaan pembelajaran sebagai pengamat dan peneliti diamati guru kelas untuk mengetahui konsitensi dalam melaksanakan metode montessori pada materi Lingkungan Sahabat Kita. Adapun lembar pengamatan aktivitas guru dalam kegiatan pembelajaran adalah

\begin{tabular}{|c|c|c|c|c|c|c|}
\hline \multirow{2}{*}{ No } & \multirow{2}{*}{ Aspek yang Diobservasi } & \multicolumn{5}{|c|}{ Penilaian } \\
\hline & & 1 & 2 & 3 & 4 & 5 \\
\hline 1. & Membuka pelajaran dan apersepsi & & & & $\sqrt{ }$ & \\
\hline 2. & Menyampaikan topik dan tujuan pembelajaran & & & & $\sqrt{ }$ & \\
\hline 3. & $\begin{array}{l}\text { Melaksanakan pembelajaran sesuai dengan rencana pelaksanaan } \\
\text { pembelajaran( RPP) }\end{array}$ & & & & $\sqrt{ }$ & \\
\hline 4. & Membagikan kelompok yang bersifat heterogen & & & & & $\sqrt{ }$ \\
\hline 5. & Membimbing diskusi kelompok yang bersifat heterogen & & & & & $\sqrt{ }$ \\
\hline 6. & Memotivasi siswa untuk bertanya dan menjawab pertanyaan & & & & $\sqrt{ }$ & \\
\hline 7. & Volume dan nada suara yang jelas & & & & $\sqrt{ }$ & \\
\hline 8. & Mengadakan Evaluasi & & & & & $\sqrt{ }$ \\
\hline 9. & $\begin{array}{l}\text { Membuat rangkuman (kesimpulan) sesuai dengan model pembelajaran } \\
\text { yang sudah ditetapkan }\end{array}$ & & & & $\sqrt{ }$ & \\
\hline 10. & Menutup pelajaran & & & & & $\sqrt{ }$ \\
\hline & Jumlah & & & 44 & & \\
\hline
\end{tabular}
sebagai berikut:

Tabel 7 Lembar Observasi Aktivitas Guru Pada Siklus II

Berdasarkan tabel diatas jumlah yang diperoleh peneliti saat bertindak sebagai guru dalam penelitian "Upaya Meningkatkan Hasil Belajar Siswa Dengan Penerapan Metode montessori Pada Tema Lingkungan Sahabat Kita Dikelas V SDN 066650 Medan Kota Tahun Pembelajaran 2020/2021" pada siklus II berjumlah $89 \%$ dengan kriteria sangat baik.

\section{Hasil Observasi Aktivitas Siswa Pada Siklus II}

Peneliti juga mengobservasi kemampuan siswa dalam mengikuti proses pembelajaran dilaksanakan dengan menggunkan metode montessori. Hasil observasi aktivitas siswa pada siklus II dapat dilihat pada table

\begin{tabular}{|c|c|c|c|c|c|}
\hline \multirow{2}{*}{ No } & \multirow{2}{*}{ Aspek yang Diobservasi } & \multicolumn{4}{|c|}{ Penilaian } \\
\hline & & 1 & 23 & 4 & 5 \\
\hline 1. & Kesiapan menerima pelajaran & & & & $\sqrt{ }$ \\
\hline 2. & Ketenangan mempelajari materi & & & & $\sqrt{ }$ \\
\hline 3. & Aktivitas kerjasama dalam kelompok & & & & $\sqrt{ }$ \\
\hline
\end{tabular}
di bawah ini:

Tabel 8 Lembar Observasi untuk Aktivitas Siswa Siklus II 
3574 Peningkatan Hasil Belajar Siswa dengan Menggunakan Metode Montessori pada Siswa Sekolah Dasar - Bisron Mangait Tua Sitinjak, Dewi Anzelina, Saut Mahulae, Patri Janson Silaban

DOI: https://doi.org/10.31004/basicedu.v5i5.1008

4. Keaktifan siswa dalam menjawab pertanyaan guru didalam kelompok

5. Keaktifan menjelaskan didepan kelas $\quad \sqrt{ }$

6. $\quad$ Tanggung jawab siswa dalam persentasi kelompok $\sqrt{ }$

7. Pemahaman siswa dalam bekerja kelompok $\sqrt{ }$

8. Penguasaan siswa dalam bekerja kelompok $\sqrt{ }$

9. Penguasaan siswa dalam mengerjakan tugas kelompok $\sqrt{ }$

10. Mengerjakan soal tes dengan baik $\sqrt{ }$

Jumlah 48

Berdasarkan tabel diatas jumlah yang diperoleh peneliti pada saat melakukan observasi aktivitas siswa pada siklus II berjumlah 48 dengan perolehan nilai 96 dan termasuk kategori sangat baik.

\section{Perbandingan Hasil Tindakan Antar Siklus}

\section{Perbandingan Hasil Tindakan Aktivitas Guru Antar Siklus}

Berdasarkan data yang diperoleh dari aktivitas guru pada siklus I dan Siklus II dapat dilihat adanya peningkatan. Dimana pada siklus I hasil observasi aktivitas guru diperoleh sebesar $78 \%$ dengan kriteria baik dan siklus II meningkat menjadi 89\% dengan kriteria sangat baik. Berdasarkan peningkatan kedua siklus ini dapat dilihat bahwa dari siklus I kesiklus II terdaopat penigkatan sebesar 15\%.

Untuk lebih jelas mengenai peningkatan hasil dari observasi aktivitas siswa dapat dilihat pada gambar grafik dibawah ini:

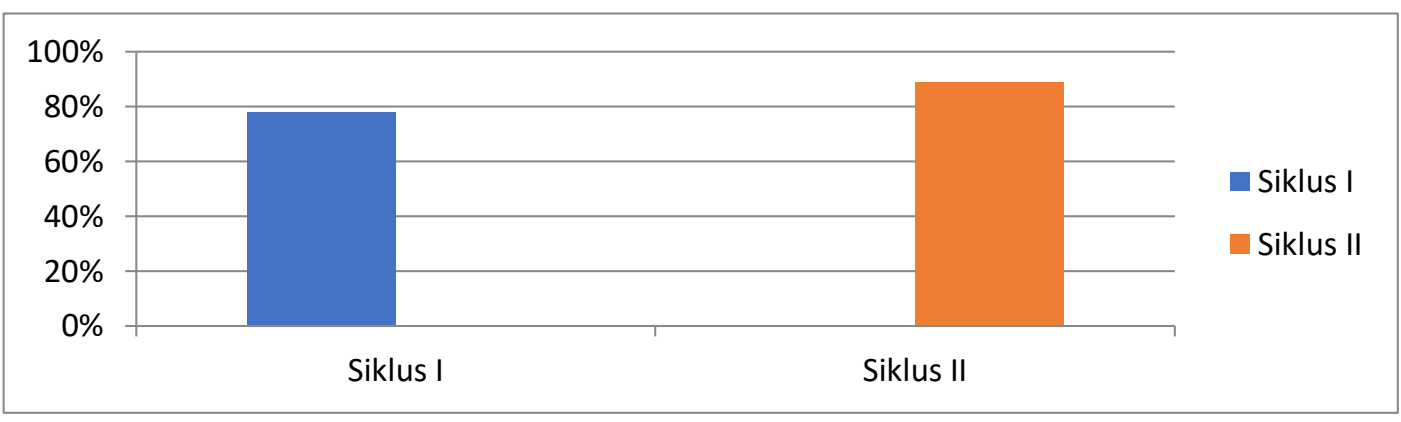

Grafik 3 Hasil Observasi Aktivitas Siswa Siklus I dan Siklus II

\section{Perbandingan Hasil Belajar Secara Klasikal Antar Siklus}

Berdasarkan data yang diperoleh dari rata-rata hasil belajar siswa dalam pelaksanaan penelitian yang dimulai dari pelaksanaan pratest, post test siklus I dan pos test siklus II dapat dilihat bahwa terdapat peningkatan hasil belajar secara klasikal pada pratest diperoleh sebesar 32\%. Pada post test siklus I ketuntasan hasil belajar meningkat menjadi $40 \%$. Pada post test siklus II ketuntasan hasil belajar meningkat menjadi $88 \%$. Peningkatan hasil belajar dari pratest ke post test I adalah $22,73 \%$ dan peningktan hasil belajar dari siklus I ke siklus II adalah sebesa 40,91\% untuk lebih jelasnya dapat dilihat pada grafik dibawah ini: 
3575 Peningkatan Hasil Belajar Siswa dengan Menggunakan Metode Montessori pada Siswa Sekolah Dasar - Bisron Mangait Tua Sitinjak, Dewi Anzelina, Saut Mahulae, Patri Janson Silaban

DOI: https://doi.org/10.31004/basicedu.v5i5.1008

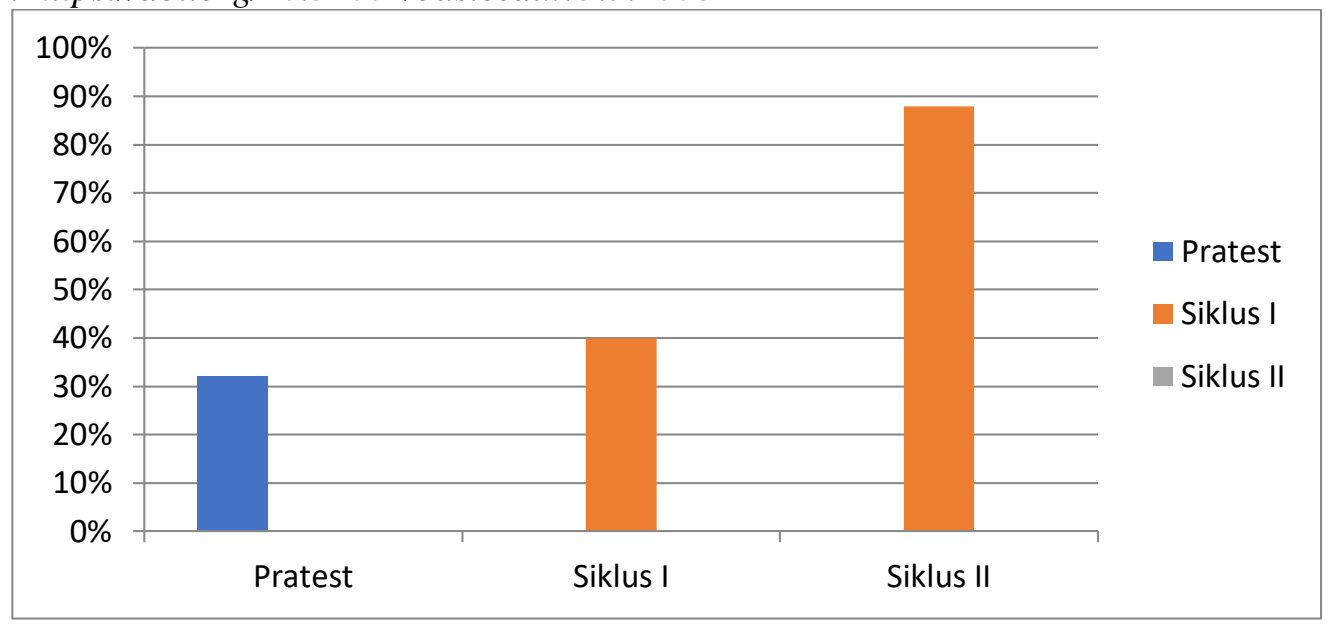

\section{Grafik 4 Perbandingan Hasil Belajar Siswa Pada Pratest, Post Test Siklus I dan Post Test Siklus II}

Pada pembahasan ini akan diuraikan temuan penelitian yang telah dianalisis dan dideskripsikan sebelumnya. Adapun yang akan dibahas pada bagian ini yaitu tentang hasil observasi aktivitas guru, hasil oservasi kegiatan siswa dan ketuntasan belajar siswa.

\section{Hasil Ketuntasan Belajar Siswa Pada Siklus I dan Siklus II}

Dari nilai hasil belajar atau ketuntasan belajar mulai dari pratest, post tes siklus I dan post test siklus II, terlihat adanya peningkatan yang baik yang dicapai siswa. Peningkatan hasil belajar siswa pada setiap siklusnya dapat dilihat pada tabel dibawah ini.

Tabel 9 Hasil Belajar Siswa Secara Klasikal

\begin{tabular}{lcc}
\hline No & Jenis Tes & Presentase Ketuntasan Klasikal \\
\hline 1 & Pra test & $32 \%$ \\
\hline 2 & Post tes siklus I & $40 \%$ \\
\hline 3 & Post tes siklus II & $80 \%$ \\
\hline
\end{tabular}

Hasil dari tabel diatas menunjukkan bahwa nilai siswa mengalami peningkatan dari dilaksanakannya post test setiap siklus. Peningkatan hasil belajar siswa pada subtema "Lingkungan Sahabat Kita" ini dapat dilihat pada gambar grafik dibawah ini:

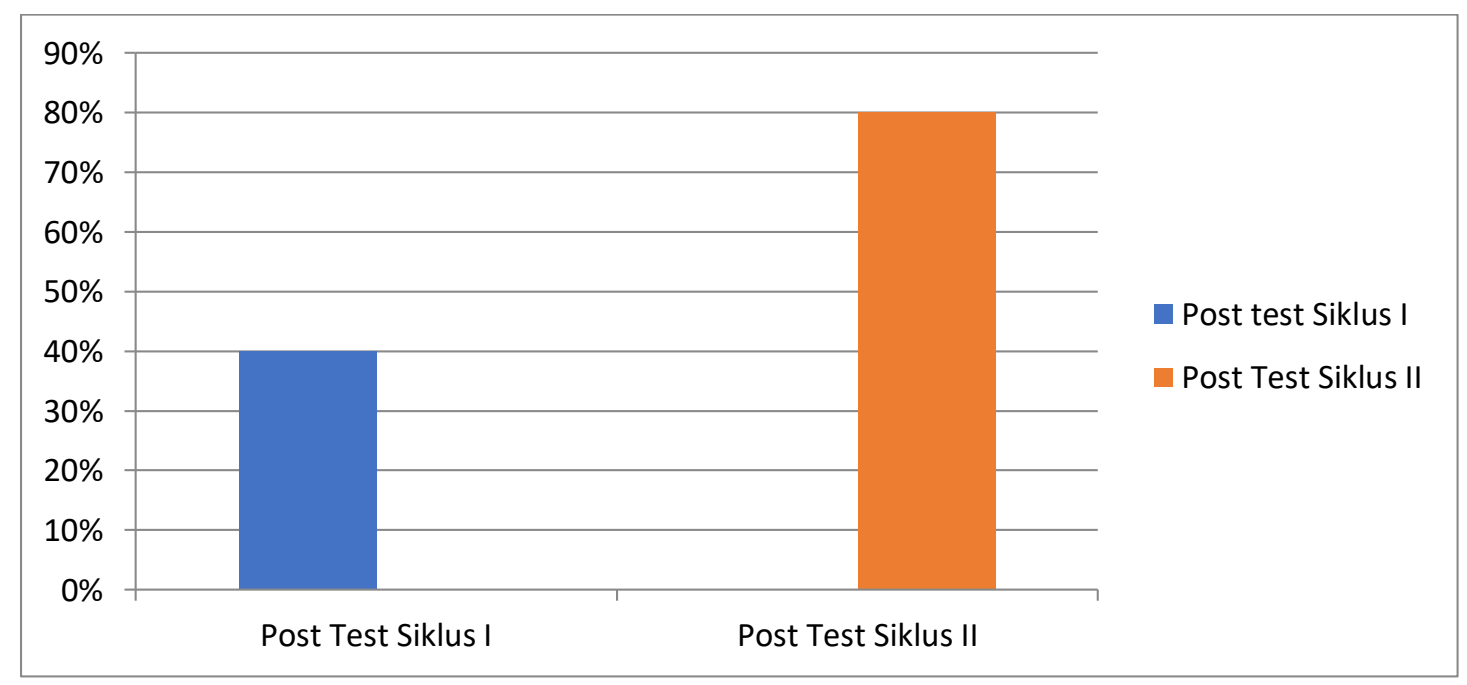

Grafik 5 Peningkatan Ketuntasan Hasil Belajar Siswa pada Post Test Siklus I Dan Post Test Siklus II 
3576 Peningkatan Hasil Belajar Siswa dengan Menggunakan Metode Montessori pada Siswa Sekolah Dasar - Bisron Mangait Tua Sitinjak, Dewi Anzelina, Saut Mahulae, Patri Janson Silaban

DOI: https://doi.org/10.31004/basicedu.v5i5.1008

Dari diagram diatas dapat dilihat bahwa pada pelaksanaan post test siklus I ketuntasan hasil belajar siswa diperoleh sebesar $40 \%$, tetapi ketuntasan hasil belajar ini belum mencapai kriteria ketuntasan klasikal yaitu $75 \%$. Siswa yang dikatakan tuntas hasil belajarnya jika terdapat $75 \%$ dari jumlah siswa yang mendapat nilai tuntas atau mencapai Kriteria Ketuntasan Minimal (KKM) yaitu 70. Oleh karena itu penelitian dilanjutkan ke siklus II. Pada post test siklus II hasil belajar siswa meningkat menjadi $80 \%$ dan mencapai kriteria ketuntasan secara klasikal, karena sudah mencapai kriteria ketuntasan secara klasikal maka penelitian ini tidak perlu dilanjutkan ke siklus selanjutnya. Penelitian ini sudah berhasil.

\section{Hasil Observasi Aktivitas Guru Siklus I dan Siklus II}

Berdasarkan data yang diperoleh dari observasi aktivitas guru pada siklus I dan siklus II, hasil observasi aktivitas guru mengalami peningkatan hasil observasi aktivitas guru pada siklus I dan siklus II dapat dilihat pada tabel dibawah ini.

Tabel 10 Hasil Observasi Guru Siklus I dan Siklus II

\begin{tabular}{llccc}
\hline No & Siklus & Skor & Persentase & Kriteria \\
\hline 1 & Siklus I & 39 & $78 \%$ & Baik \\
\hline 2 & Siklus II & 44 & $89 \%$ & Sangat Baik \\
\hline
\end{tabular}

Dimana pada siklus I hasil observasi hasil observasi aktivitas guru diperoleh sebesar $78 \%$ dengan kriteria baik dan pada siklus II meningkat menjadi 89\% dengan kriteria sangat baik. Berdasarkan peningkatan kedua siklus ini dapat dilihat bahwa dari siklus I dan siklus II terdapat peningkatan $11 \%$ untuk lebih jelasnya dapat dilihat pada gambar dibawah ini.

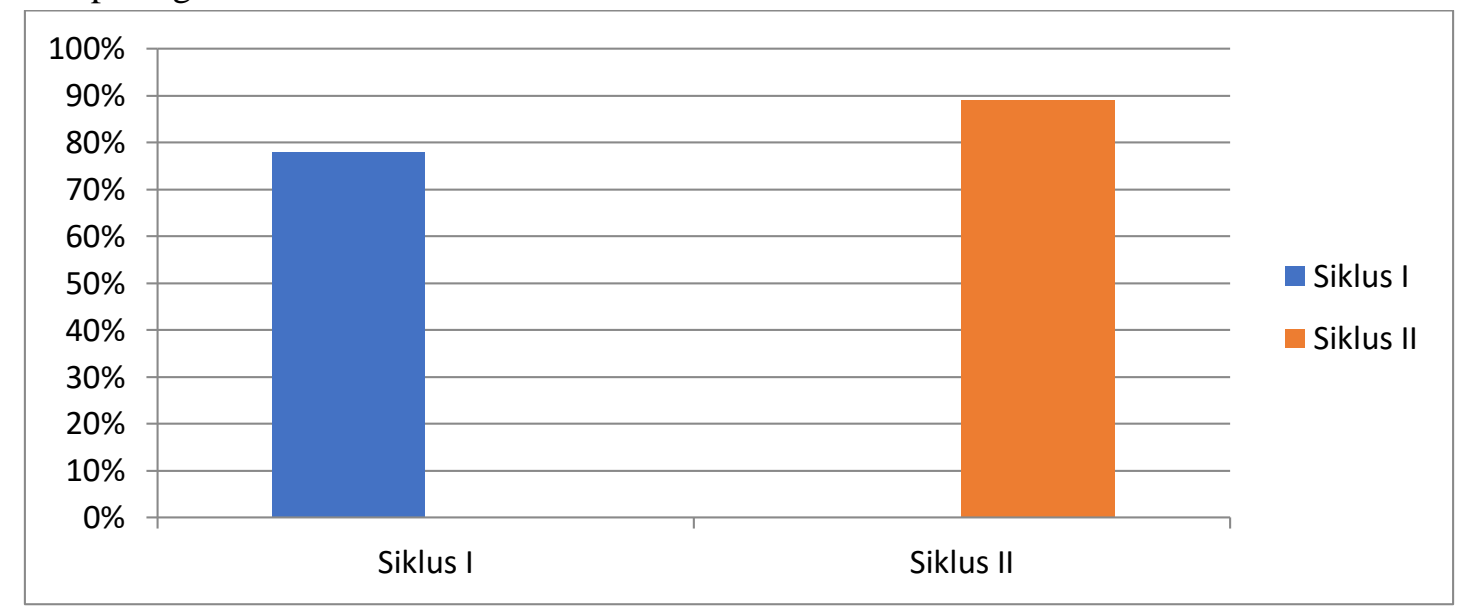

Grafik 6 Hasil Observasi Aktivitas Guru pada Siklus I dan Siklus II

\section{Hasil Observasi Aktivitas Siswa Siklus I dan Siklus II}

Dari hasil penelitian yang telah dilakukan penelitian diperoleh hasil aktivitas siswa yang dapat kita lihat pada tabel berikut:

Tabel 11 Hasil Observasi Aktivitas Siswa Siklus I dan Siklus II

\begin{tabular}{ccccc}
\hline No & Siklus & Skor & Nilai & Kriteria \\
\hline 1 & Siklus I & 34 & 68 & Cukup \\
\hline 2 & Siklus II & 48 & 96 & Sangat Baik \\
\hline
\end{tabular}

Berdasarkan tabel diatas pada siklus I hasil observasi aktivitas siswa diperoleh nilai sebesar 68 dengan kriteria cukup dan pada siklus II meningkat menjadi 96 dengan kriteria sangat baik. Berdasarkan peningkatan kedua siklus ini dapat dilihat bahwa dari siklus I ke siklus II terdapat peningkatan 28. 
3577 Peningkatan Hasil Belajar Siswa dengan Menggunakan Metode Montessori pada Siswa Sekolah Dasar - Bisron Mangait Tua Sitinjak, Dewi Anzelina, Saut Mahulae, Patri Janson Silaban

DOI: https://doi.org/10.31004/basicedu.v5i5.1008

Untuk lebih jelasnya mengenai peningkatan hasil observasi aktivitas siswa dapat dilihat pada gambar grafik dibawah ini:

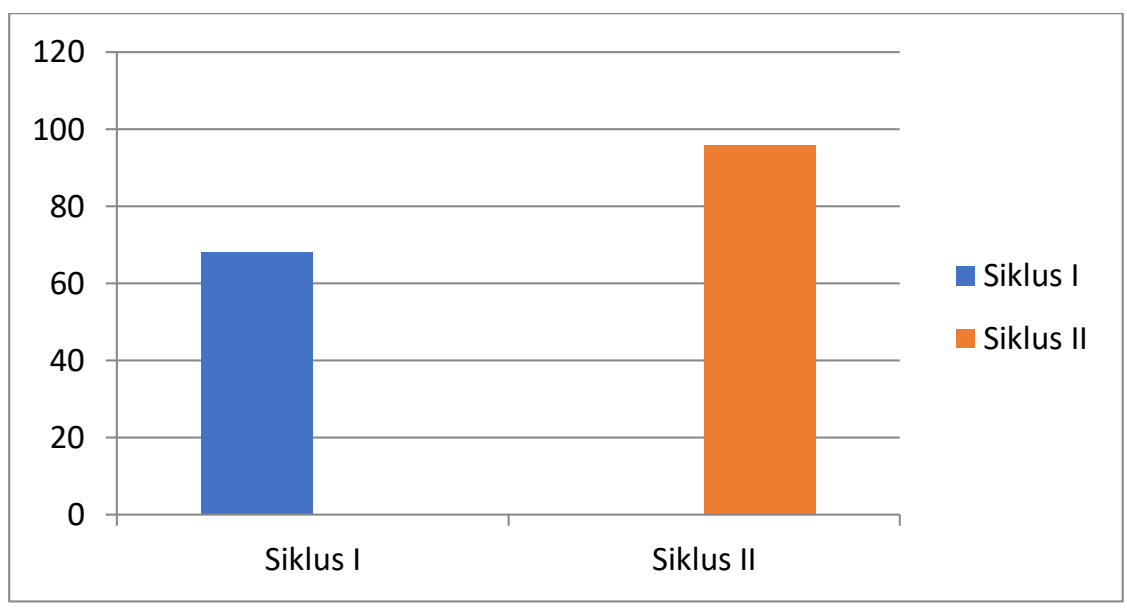

Grafik 7 Hasil Observasi Aktivitas Siswa pada Siklus I dan Siklus II.

\section{KESIMPULAN}

Berdasarkan hasil penelitian yang dilakukan oleh peneliti dengan menggunakan metode montessori bahwa pembelajaran tematik dapat meningkatkan hasil belajar siswa kelas V SD Negeri 066650 Medan Kota, bahwa data yang diperoleh dari aktivitas guru pada siklus I dan Siklus II dapat dilihat adanya peningkatan kedua siklus ini dapat dilihat bahwa dari siklus I kesiklus II terdaopat peningkatan sebesar $15 \%$. Rata-rata hasil belajar siswa dalam pelaksanaan penelitian yang dimulai dari pelaksanaan pratest, post test siklus I dan pos test siklus II dapat dilihat bahwa terdapat peningkatan hasil belajar secara klasikal pada pratest diperoleh sebesar $32 \%$.

Data yang diperoleh dari observasi aktivitas guru pada siklus I dan siklus II, hasil observasi aktivitas guru mengalami peningkatan dilihat bahwa dari siklus I dan siklus II terdapat peningkatan $11 \%$. Hasil observasi aktivitas siswa diperoleh peningkatan kedua siklus ini dapat dilihat bahwa dari siklus I ke siklus II terdapat peningkatan 28 .

\section{UCAPAN TERIMA KASIH}

Peneliti mengucapkan terimakasih kepada semua pihak yang terlibat dalam penelitian ini. Secara khusus buat program studi PGSD FKIP Universitas Katolik Santo Thomas Medan, yang telah membantu peneliti secara langsung dan tidak langsung sehingga penelitian dapat di selesaikan dan di laporkan secara tertulis.

\section{DAFTAR PUSTAKA}

Anzelina, Dewi. 2020. "Perbedaan Model Pembelajaran Mind Mapping Dengan Model Pembelajaran Problem Based Learning Dalam Meningkatkan Hasil Belajar Siswa Pada Mata Pelajaran Ipa Kelas Iv Sd Negeri 068003 Medan.” Jurnal Ilmiah Aquinas Iii(2):249-65.

Arum, Putri Sekar. 2019. Peningkatan Hasil Belajar Siswa Kelas Iv Sd Menggunakan Media Pembelajaran Ipa Berbasis Metode Montessori Pada Materi Perakaran Tumbuhan.

Asrohah, Hanum. 2015. Pembelajaran Tematik.

Fajarwati, Indah. 2014. Konsep Montessori Tentang Pendidikan Anak Usia Dini Dalam Perspektif Pendidikan Islam. Vol. Xi. 
3578 Peningkatan Hasil Belajar Siswa dengan Menggunakan Metode Montessori pada Siswa Sekolah Dasar - Bisron Mangait Tua Sitinjak, Dewi Anzelina, Saut Mahulae, Patri Janson Silaban DOI: https://doi.org/10.31004/basicedu.v5i5.1008

Ferisa, Paranimita, Widodo, Satriyani, Ayun, And Akbar. 2017. Implementasi Pembelajaran Tematik Di Sekolah Dasar. 2nd Ed. Bandung: Pt Remaja Rosdakarya.

Lumban Gaol, Rumiris, Universitas Katolik, And Santo Thomas. 2020. "Efektifitas Media Pembelajaran Berbasis Berang Bekas Terhadap Motivasi Belajar Siswa Pada Pembelajaran Tematik." 4(4):51-57.

Muklis, Mohamad. 2012. "Pembelajaran Tematik Pembelajaran Tematik Mohamad Muklis Stain Samarinda." Fenomena $\operatorname{Iv}(20): 63-76$.

Ngalimun. 2017. Pembelajaran Terpadu. 1st Ed. Yogyakarta: Parama Ilmu.

Noor. 2017. Metodologi Penelitian. 7th Ed. Jakarta.

Orisa, Prastiwi Vincentia. 2016. "Pengembangan Alat Peraga Pembelajaran Matematika Untuk Siswa Kelas Iii Sd Materi Perkalian Berbasis Metode Montessori Skripsi."

Paramita. 2019. Jatuh Hati Pada Montessori. 7th Ed. Bandung: Pt Bentang Pustaka.

Pengembangan, Pembelajaran Dan, Bahan Ajar, And Dalam Pendidikan. N.D. Pembelajaran Dan Pengembangan Bahan Ajar Dalam Pendidikan.

Pulungan, And Istirani. 2017. Ensiklopedi Pendidikan. 2nd Ed. Medan: Media Persada.

Risjayanti. 2008. "Peningkatan Motivasi Dan Minat Belajar Siswa Dalam Pembelajaran Matematika Melalui Metode Montessori Dengan Menggunakan Alat Peraga."

Savitri. 2019. Aktivitas Montessori Ilmu Alam Dan Matematika. 1st Ed. Edited By Aulia. Jakarta Selatan.

Silaban, Patri. 2019. "Penerapan Model Pembelajaran Inkuiri Untuk Meningkatkan Hasil Belajar Siswa Pada Mata Pelajaran Matematika Di Kelas Vi Sd Negeri 066050 Medan Tahun Pembelajaran 2018/2019.” Jurnal Ilmiah Aquinas Ii(1):107-26.

Slameto. 2015. Belajar Dan Faktor-Faktor Yang Mempengaruhi. 6th Ed. Jakarta: Pt Rineka Cipta.

Sugiono. 2018. Metode Penelitian. 1st Ed. Bandung: Alfabeta.

Supardi, Suhardjono, And Arikunto. 2017. Penelitian Tindakan Kelas. 1st Ed. Jakarta: Pt Bumi Aksara.

Syafri, Fatricia. 2013. Maria Montessori, (Gerald Lee Gutek, Ed.)., Metode Montessori . (Yogyakarta:Pustaka Pelajar, 2013). H.1-5.

Syah. 2018. Psikologi Belajar. 14th Ed. Depok.

Tanjung, Darinda Sofia. 2016. "Meningkatkan Hasil Belajar Ips Siswa Dengan Menerapkan Model Pembelajaran Kooperatif Tipe Team Games Tournament (Tgt) Di Kelas V Sdn 200111 Padangsidimpuan.” Juril Amik Mbp Iv(1):68-79.

Wulandari, Dewi Asri, And Jajang Aisyul Muzakki. 2018. "Implementasi Pendekatan Metode Montessori Dalam."

Zaenul, And Haryanti. 2020. Metodologi Penelitian Pendidikan. 1st Ed. Malang: Madani Media.

Zahidi, Afif. 2020. "Analisis Metode Montessori Pada Pembelajaran Matematika Bagi Siswa Usia Dasar ( Jenjang Mi / Sd ).” Pgmi Stti Al-Ittihadiyah Labuhanbatu Utara I(4):245-60.

Zain, And Djamarah. 2016. Strategi Belajar Mengajar. Jakarta: Rineka Cipta.

Zain, And Djamarah. 2017. Strategi Belajar Mengajar. 3rd Ed. Jakarta: Pt Rineka Cipta. 